\title{
Reducing vehicle-related NOx and PM emissions in metropolitan areas: A comparison between the Randstad and the Rhine-Ruhr area
}

\author{
Robert Haakman ${ }^{\mathrm{a}, 1}$, Ivo Beenakker ${ }^{\mathrm{b}, 1}$, Harry Geerlings a, * \\ a Department of Public Administration, Erasmus University Rotterdam, Burgemeester Oudlaan 50, 3062 PA, Rotterdam, the Netherlands \\ ${ }^{\mathrm{b}}$ Nijmegen School of Management, Radboud University, Heyendaalseweg 141, 6525AJ, Nijmegen, the Netherlands
}

\section{A R T I C L E I N F O}

\section{Article history:}

Received 9 March 2019

Received in revised form

6 October 2019

Accepted 4 November 2019

Available online 6 November 2019

Handling editor: Panos Seferlis

\section{Keywords:}

Nitrogen oxides (NOx)

Particulate matter (PM)

STREAMS model

Policy instruments

Incentives

Technology

\begin{abstract}
A B S T R A C T
With scientific discoveries indicating a relationship between nitrogen oxides/particulate matter and cancers/heart disease, and the growing road transport sector in Western Europe, there is an increasing urgency to further reduce vehicle emissions. This comprises a large part of the total emissions in urban areas. In this article, we address the question of how various local policy instruments and technology can be used to support the use of clean road vehicles in urban areas. Despite some moderate success in specific areas, local policies and technology need to become even more effective.

Using the STREAMS model, a comparative analysis is made of six urban cases in the Randstad and the Rhine-Ruhr metropolitan areas. The study provides new insights into the dynamics between the perceived problems, policy making (in terms of the adoption of policy instruments), politics (in terms of the fit/misfit between stakeholders' interests, which may result in a window for policy change), and technology. The policy instruments examined include low emission zones, parking licence restrictions, and incentives to adopt electric vehicles. Policy recommendations are made regarding effective policy instruments for the reduction of harmful emissions in metropolitan areas. Implications for theory are also discussed.
\end{abstract}

(c) 2019 Elsevier Ltd. All rights reserved.

\section{Introduction}

Since late in the twentieth century, much research has been conducted on the effects of vehicle emissions on health. In the 1970 s, research focussed on the direct effects of a wide range of contaminants related to local and regional impacts of traffic, including nitrogen oxides (NOx), sulphur oxides (SOx), carbon monoxide ( $\mathrm{CO})$, and ozone $\left(\mathrm{O}_{3}\right)$. The results of these studies showed that, with short-term exposure, people with hyper-reactive airways experienced a decrease in pulmonary function and increased heart rate (Hackney et al., 1975). Long-term studies showed that daily exposure to these emissions increases the chances of respiratory problems such as asthma (Spengler et al., 1979). In the 1990s, several studies were conducted on the short-term effects of harmful emissions. Data from Western European cities indicated that an increase of $50 \mu \mathrm{g}$ per cubic metre $\left(\mu \mathrm{g} / \mathrm{m}^{3}\right)$ of sulphur dioxide

\footnotetext{
* Corresponding author.

E-mail address: h.geerlings@essb.eur.nl (H. Geerlings).

1 The order of the first two authors is chosen randomly. The first two authors have made an equal contribution.
}

correlated with a $3 \%$ increase in mortality. For particulate matter $\left(\mathrm{PM}_{10}\right)$, the increase in mortality was $2 \%$ (Katsouyanni et al., 1997).

In the early 2000s, studies were conducted on the effects of harmful emissions in the longer term. These studies indicated that an increase in the aforementioned harmful emissions, leads to an increase in mortality and hospital admissions consequent to cardiovascular and respiratory disease, with effects seen at very low levels of exposure (Brünekreef and Holgate, 2002). A World Health Organization study showed that vehicle emissions comprise approximately $30 \%$ of the total harmful emissions in cities, except for NOx emissions, to which road transport is the main contributor (40-50\%). These emissions are concentrated mostly in structures such as tunnels, street canyons, and motorways (WHO, 2005). More recent studies have revealed a relation between high PM levels and lung cancer and cardiovascular/cardio-pulmonary diseases among people, living in polluted areas, who have never smoked (Valavanidis et al., 2008, 2013). According to the European Environment Agency, approximately 400,000 annual premature deaths in the European Union are caused by exposure to high PM levels. Another 70,000 premature deaths occur from exposure to $\mathrm{NO}_{2}$ in the European Union (Adams, 2017). 
Given the serious impacts of transportation on public health, municipalities of larger cities in Western Europe had to come up with policy measures to reduce road vehicle emissions, including Low Emission Zones (LEZ), reducing lanes in busy city streets, parking licence restrictions for old petrol and diesel cars and even an LEZ for scooters in Amsterdam (Municipality of Amsterdam, 2018c). So far, the effects of LEZs has been researched in different cities. A study in London on the effects of the LEZ on vehicles and air quality showed a decline of $20 \%$ in pre-Euro 3 heavy vehicles and of 10\% for light vehicles from 2008 to 2013. Furthermore, PM levels declined by $2.75 \%$, but NOx levels remained constant (Ellison et al., 2013). In Lisbon, implementing a two tier LEZ had led to a reduction of $29 \%$ for $\mathrm{PM}_{10}$ and $12 \%$ for $\mathrm{NO}_{2}$ in Zone One from 2009 to 2016 , while $\mathrm{PM}_{10}$ levels had dropped by $23 \%$ and $\mathrm{NO}_{2}$ levels by $22 \%$ in Zone Two in the same period (Santos et al., 2019).

In Western Europe, the Randstad (the Netherlands) and the Rhine-Ruhr metropolitan areas (Germany) comprise many cities that have experienced many measures to reduce vehicle-related air pollution. Utrecht was one of the earliest cities to adopt a LEZ, starting in 2007. Other cities in the Netherlands and Germany followed shortly after. In Germany, the first LEZs were initiated in Cologne, Berlin and Hannover in 2008. In 2009, the LEZ was adopted in Dusseldorf. Since 2008, the LEZ has also been launched in Duisburg (as part of the Ruhr LEZ) (Municipality of Duisburg, 2019). Today, around 70 German cities have a LEZ within their municipal borders. A study of the effects of two stage LEZs in 25 German cities estimates the saved costs in health care to be around $€ 760$ million with only one stage and $€ 2.5$ billion with two stage LEZs (Malina and Scheffler, 2015). Given that vehicles contribute significantly to higher PM and NOx emissions in urban areas, our study focuses on local policy instruments and technology aiming to reduce NOx and PM levels in the Randstad (Amsterdam, Rotterdam, Utrecht) and Rhine-Ruhr (Cologne, Dusseldorf, Duisburg) metropolitan areas. These two metropolitan areas have a high-density population, a comparable economic structure, several logistic hubs and common commuting patterns between cities. The average population density in the Netherlands was 510 inhabitants per $\mathrm{km}^{2}$ in 2018 . The population density in the Randstad varied between 6459 inhabitants per $\mathrm{km}^{2}$ in The Hague and 2936 inhabitants per $\mathrm{km}^{2}$ in Rotterdam (CBS, 2019a). Today in Germany, the average population density is 232 inhabitants per $\mathrm{km}^{2}$. In the Rhine-Ruhr area, the population density is between 2142 inhabitants per $\mathrm{km}^{2}$ (Duisburg) and 2849 inhabitants per $\mathrm{km}^{2}$ in Dusseldorf (Statistisches Bundesamt, 2019). Both metropolitan areas have a strong focus on the service sector. In the two metropolitan areas identified, there is a remarkable commuting pattern between the different cities in the metropolitan area (above 80 percent of the total urban transport occurs in the metropolitan area) (Swinney, 2016).

The implementation of some policy measures has not been without controversy. In Dutch cities, especially LEZs for personal vehicles have met resistance and legal action from vehicle associations KNAC, BOVAG and upset citizens who cannot use their older diesel (<Euro 5) or petrol cars $(<1992)$ in the city centre. This has led to a withdrawal of the LEZ ordinance for petrol cars, followed again by a newly reinstated ordinance for this category in the case of Rotterdam. In 2018, the German Federal Court allowed after a constitutional case, German municipalities to forbid vehicle movements to restrict vehicle-related PM and NOx emissions. Today, the EU is pushing for stricter emissions reductions because, except in the LEZs, vehicle-related air pollution in 70 German cities still exceeds EU air quality norms (Balser and Bauchmüller, 2018). These cases show that consensus on the problem of air pollution cannot be taken for granted, let alone the policy solutions proposed to reduce NOx and PM emissions. Stakeholders' interests can influence perceptions of the problem and the perceived effective and legitimate policy solutions. Given the difficulties in implementing effective local governmental policy to reduce vehiclerelated NOx and PM emissions, it is likely that solutions for the longer term should be more oriented towards an integrated policy. Integrated policy includes a diverse range of local policy instruments that address different problem statements and stakeholder interests. Therefore, the main research question of this study is the following:

How can local mobility policies and technologies be adopted among different actors to reduce vehicle-related NOx and PM levels in the Randstad and the Rhine-Ruhr metropolitan areas, and to what extent have these local mobility policy and technologies been successful?

To explore this main research question, the article addresses three sub-questions:

1. What local mobility policies to reduce NOx and PM emissions from road vehicles have been adopted in the Randstad and the Rhine-Ruhr metropolitan areas?

2. How can technologies support the reduction of road vehicle emissions in the Randstad and the Rhine-Ruhr metropolitan areas?

3. To what extent have local mobility policies and technologies been successful in the reduction of vehicle-related NOx and PM levels in the Randstad and the Rhine-Ruhr metropolitan areas?

The scientific contribution of this paper lies in the elaboration of the effects of local policy instruments approached from the perspective of the STREAMS model (Kingdon, 1984). The STREAMS model demonstrates how the fit between problems, policy, and politics can create a policy window for an effective reduction of NOx and PM emissions from vehicles in urban areas. The infrasystem (Loorbach et al., 2010; see section 3.2) includes an additional stream of technology that explains how certain effective clean-vehicle technologies can make breakthroughs possible. The infrasystem entails the combination of hardware technology and organizational structures (Loorbach et al., 2010) that may have influence on local emission levels. A breakthrough or transition occurs in situations where political opposition means that oldfashioned emission-controlling policy instruments are losing their efficacy and are replaced by new and innovative policy instruments. Therefore, the dynamic interaction between perceived problems, various policy instruments, stakeholders' interests, and technology needs to be understood. Besides the adoption of the STREAMS model, this study makes necessary alterations to the STREAMS model, in particular concerning the policy and the (added) technology STREAMS.

From a societal perspective, this study is important, because it explains the ongoing policy struggle against air pollution from vehicles in the Randstad and the Rhine-Ruhr metropolitan areas. In recent years, air pollution has been reduced to a certain extent, because of different local policy measures. Today, because of the growing economy and manufacturers' greater difficulty in complying with the Euro 6 norms, vehicle emissions could increase again in the coming years. This paper contributes to the improvement of air quality in cities by analysing the effectiveness of local policy instruments under different governance conditions and demonstrates their efficacy or shortcomings. The two metropolitan areas studied show quite some similarities with Paris, London, Milan and other urbanised areas in Europe as well, which means that the findings are neither case specific nor relevant for specific geographical areas.

The structure of the article is as follows. In section two, we provide a clarification on the adopted methodology. Section three 
elaborates the STREAMS model (Kingdon, 1984) as framework for explaining how a sudden fit between problems, policies and politics could become an opportunity for effectuating local mobility policy and sustainable technology. Section four provides an overview of the adopted policy instruments in the Randstad respectively the Ruhr-metropolitan area, the available sustainable technologies that mitigate the negative externalities of transport-related emissions and depicts vehicle-related emissions in both metropolitan areas. In section five, we draw conclusions and give recommendations for future research on the evaluation of vehicle-related local policy instruments and sustainable technology adoption.

\section{Methodology}

The research incorporates an interpretative policy analysis where the effects of local policy instruments on air pollution from vehicles are analysed. Interpretative policy analysis focuses on the meaning, both in expression and in communication, of policies (Yanow, 2014). Public policies are the expressions of stories that identify problems, politics and solutions (Kingdon, 1984) for a group of actors (with the risk to have a conflicting story to other actors). The process of interpretative policy analysis includes the qualitative analysis of mobility-related environmental problems, local policy instruments that apply to vehicles, actor identification, emission(s) specification, emission thresholds and regulations, sustainable technology specifications and media coverage. The choice of an interpretative analysis on local policy instruments is based on the minor or mediocre effects and functions that certain local policy instruments have had in recent years on reducing vehicle emissions and on improving air quality in major cities in the Randstad and the Rhine-Ruhr metropolitan areas. Moreover, an interpretive analysis of the circumstances in which local policy instruments and technologies have been implemented and the effects that they have brought about can provide better insights into how further air quality improvements in city centres could be achieved. In addition, the interpretative analysis of local policy instruments provides insights into the interactions between problem perceptions, stakeholders' interests, and policy or technological instruments. It allows the choices made by policy actors to be mapped and analysed in the context in which the policy decisions have been taken. Thus, the interpretative analysis of local policy instruments enables the researchers to evaluate problems, policy solutions and politics (Kingdon, 1984) based on the interpretation of environmental policies, quantitative data on emissions, technological specifications and media coverage. Furthermore, we have made a cross-case comparison between the Randstad and the Rhine-Ruhr metropolitan areas by systematically mapping similarities and differences. For each city (Amsterdam, Rotterdam, Utrecht, Cologne, Dusseldorf and Duisburg), we have identified the policy problem, the stakeholder's interest, LEZ, parking license restrictions, alternative infrastructures, support for electric vehicle, motorway toll, LEZ info system, NOx and PM emittances. In this way, we investigate the adoption of local policy instruments and technology in a real-life context, while the boundaries between the policy instruments and technology are not clearly distinguishable (Yin, 2013). In other words, we can only understand the impact of local policy instruments and technology by examining them in their context.

The choice of a case study is based on the need to compare different problem perceptions, policy instruments, stakeholders' interests, and technologies adopted in Amsterdam, Rotterdam, Utrecht, Cologne, Dusseldorf, and Duisburg. The choice for the Randstad and the Rhine-Ruhr metropolitan areas is based on the notion that both the Randstad and the Rhine-Ruhr metropolitan area are the economic core regions in the Netherlands respectively in Germany. Therefore, EU emission thresholds may be exceeded due to a large number of economic activities and mobility movements. In addition, the Randstad and the Rhine-Ruhr metropolitan areas have differences in the adoption of sustainable mobility policy. For instance, car users are required to have mobility stickers in the Ruhr metropolitan area, while Amsterdam adopts a restrictive parking policy. With these comparisons, a good overview can be obtained of whether policy problems have been resolved sufficiently by current technologies, or whether policies and their instruments have had an undesired effect on air pollution. It needs to be stressed that the focus of this study is on the actual emissions due to the present performance during vehicle operations. The study excludes the life-cycle analysis-aspects of the technologies as for instance the availability of scarce resources for battery production or the related pollution during production and disposal of these batteries.

\section{Theory}

\subsection{The STREAMS model}

According to Kingdon (1984), policy agendas result from the confluence of three STREAMS or flows, namely, problems, policies, and politics. These STREAMS are constantly changing in priorities and content, because of the influence of different actors. When these STREAMS come together, an opportunity presents itself whereby policy entrepreneurs actively try to influence the stream of policy solutions by introducing the solutions that benefit them the most. Following, they try to couple these measures to the other related problems and politics. The coupling of these STREAMS is called a policy window and an opportunity for policy change, for instance in favour of the reduction of vehicle-related NOx and PM levels in the Randstad and the Rhine-Ruhr metropolitan areas. The STREAMS model is an appropriate conceptual model to explain policy dynamics, because the STREAMS model addresses the blurry and incremental nature of policy processes. In policy practice, it is often far from clear which actors, problems, policies and politics affect the outcome of policy processes.

Consequently, policy entrepreneurs act as pragmatic policy actors who attempt to fit perceived problems with policy solutions by espousing politics. The blurry interplay between problems, politics and policy solutions appears in the fact that a particular problem definition may be the result of a particular policy solution, where you would expect that a problem be prior to a policy solution. Furthermore, the presence of capable and ambitious policy entrepreneurs may support a sudden policy window opportunity between problems, solutions and politics. Indeed, the relation between problems, solutions and politics is not clear beforehand and so contributes to the fuzzy nature of policy development.

The fuzzy nature between problems, solutions and politics appears in the different effects of LEZ's on emission levels in Coimbra, Greater London, 25 German cities, Amsterdam and Lisbon. On the one hand Dias et al. (2016) observed that private vehicle-related $\mathrm{PM}_{10}$ and $\mathrm{NO}_{2}$ emissions decreased significantly with $63 \%$ and $52 \%$ respectively in the LEZ of Coimbra. At the city level, however, $\mathrm{PM}_{10}$ and $\mathrm{NO}_{2}$ emission levels increased despite the LEZ. Although not very effective on a city-level, LEZ was supposed to be the solution to the problem of air pollution. As part of the politics, the government of Portugal was required to make Action Plans for areas that do not comply with EU emission norms. The directives set by the European Union and the national Action Plan influenced the city government of Coimbra to adopt LEZ. In the LEZ of Greater London, government adopted minimum emission standards on heavy diesel vehicles, buses, coaches and (later) light commercial 
vehicles. To this date, however, it remains unclear how successful LEZs were in terms of meeting the emission standards. Moreover, NOx levels showed no discernible differences before and after the launch of LEZ. The only discernible policy effect of the LEZ on the aforementioned vehicles classes was a higher fleet turnover in Greater London (Ellison et al., 2013). In conclusion, in Coimbra and Greater London, LEZ had a mixed effect on urban air quality.

On the other hand, a number of studies show lower vehiclerelated emissions as the result of the interplay between policy problems, politics and policy solutions. According to Malina and Scheffler (2015), the adoption of LEZ in 25 German cities (in total 3.96 million inhabitants) resulted in reduced $\mathrm{PM}_{10}$ emission levels. Furthermore, due to reduced air pollution, the total mean health impact was $€ 760$ million in stage 1 LEZs in the 25 German cities. In addition, the total mean health impact was $€ 2.4$ billion in the more stringent stage 2 LEZs. Panteliadis et al. (2014) found that due to the introduction of LEZ in Amsterdam, the traffic contribution concentrations compared to the roadside site concentrations decreased. More specifically, $\mathrm{NO}_{2}$ declined with 4.9\%, NOx decreased with $5.9 \%$ and $\mathrm{PM}_{10}$ declined with $5.8 \%$. Santos et al. (2019) observed lower annual vehicle-related emissions due to the introduction of a LEZ in Lisbon. As earlier mentioned, from 2009 to 2016 vehicle-related $\mathrm{NO}_{2}$ levels declined there with $12 \%$ and $\mathrm{PM}_{10}$ concentrations with $29 \%$ respectively in LEZ zone 1 annually. In LEZ zone $2, \mathrm{NO}_{2}$ concentrations fell with $22 \%$, while $\mathrm{PM}_{10}$ levels dropped with $23 \%$. In addition, several studies demonstrate that the implementation of LEZs, mostly for old diesel vehicles, has had a some effect on improving air quality in cities. A study in $12 \mathrm{EU}$ countries and 200 cities showed that NOx and PM levels in the air have been reduced by $3-4 \%$ in regular LEZs over the last few years (Holman et al., 2015). The reduction in harmful emissions can be $6-8 \%$, especially in polluted cities with more restrictive LEZs (Gehrsitz, 2017). In conclusion, in 25 German cities, Amsterdam, Lisbon and in 12 different EU countries, the air quality improved as the result of the introduction of LEZ.

The contradictory effects of LEZ on urban emission levels show that solely the interplay between policy problems, politics and policy solutions, do not sufficiently explain policy influence in terms of lower vehicle-related emissions as the result of LEZ. After all, the prior studies show mixed results of the effect of LEZ on $\mathrm{NO}_{2}$ and PM emissions. Therefore, another 'stream' may effect urban emission levels. Therefore, we propose a renewed STREAMS model that provides a better policy explanation for reduced vehiclerelated NOx and PM levels in the Randstad and the Rhine-Ruhr metropolitan areas.

\subsection{Towards a renewed STREAMS model}

Besides the perceived problems, policy instruments, and politics in the STREAMS model, a fourth stream is incorporated into the model, namely, technology (see Fig. 1). Technology does not consist solely of the physical components of a technological system; rather, it is embedded in organizational and institutional structures that together make the technology 'work'. Loorbach et al. (2010) use the term infrasystem to denote the combination of technological hardware and organizational and institutional structures that together are vital for mobility systems to function properly. Technology is considered the fourth stream in the STREAMS model, because emission-reducing technology can function properly only if the perceived environmental problems and stakeholders' interests are addressed and the local policy instruments make the adoption of sustainable technology possible.

With this adaptation - combining the perceived problem, local policy, politics, and technology STREAMS - the STREAMS model becomes applicable to the case of vehicle emissions in metropolitan areas. Most actors perceive polluting vehicles as the main environmental problem. Politicians, policymakers, associations, companies, and industry producers have a stream of interests concerning emission level reduction. These interests result in a stream of constantly changing policy instruments that can further or hinder progress. These instruments can be categorized as local policy and technology.

Policy instruments can be analysed regarding their effectiveness by its impact on harmful pollutants in the air (NOx, PM, and so forth). The technology STREAM includes two approaches. The first approach is a high-cost approach for a small number of consumers (trendsetters) and government contracts with the adoption of policy incentives. In this approach, emission reductions (-\%) and cost effectiveness are important indicators (-\% emissions per $€ 1000$ invested in cleaner technologies). The other approach is a low-cost approach that aims at a large number of consumers and companies. With this approach, the buying impulses generated by market instruments and information is of greater importance. As a result, cost efficiency ( $€$ per $-1 \%$ emissions) is an important indicator. In summary, the renewed STREAMS model includes problems, politics, policy instruments and technology, by which policy instruments include a high-cost and a low-cost approach.

\section{Analysis}

There are increasing calls for greater policy integration in the

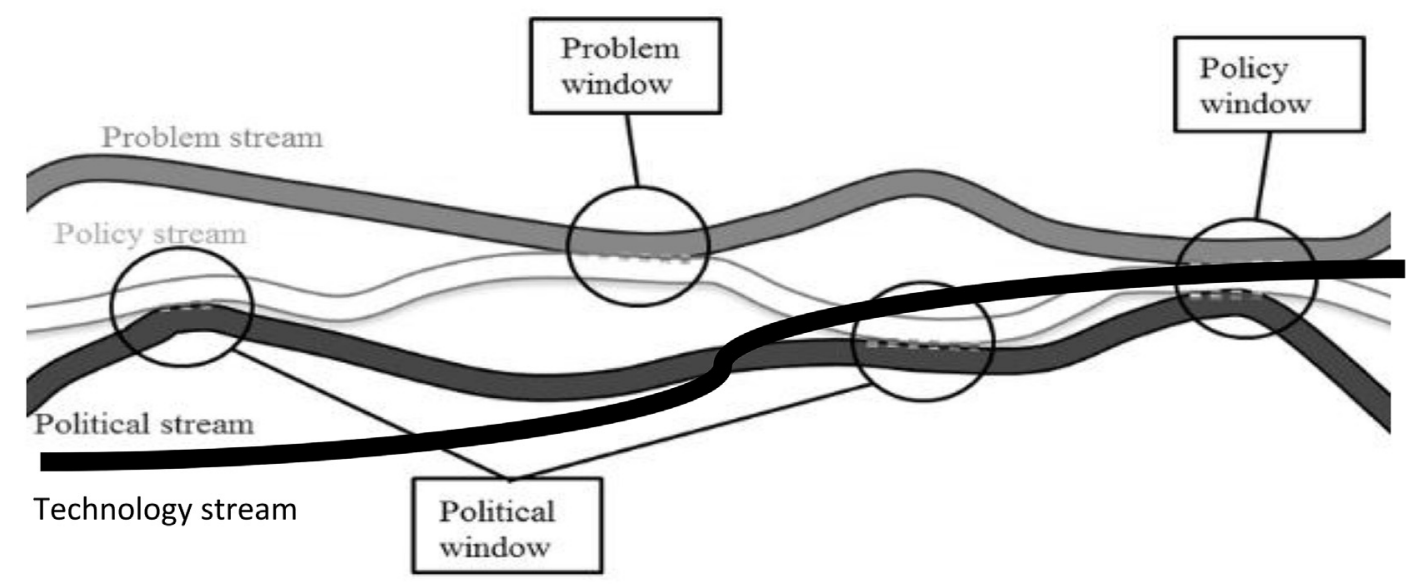

Fig. 1. The STREAMS model, with the fourth stream 'technology'. Source: Kingdon (1984) as cited in Enserink et al. (2012). Adapted by the authors. 
mobility sector. Various types of policy integration exist (for a more detailed review see Geerlings and Stead, 2003), such as coherent policymaking, crosscutting policymaking, policy coordination, and holistic government, also known as joined-up policy or joined-up government. Policy integration is also visible in the transport sector. The transport sector is a complex system that depends on multiple actors and factors, including the pattern of human settlements and consumption, the organization of production, and the availability of infrastructure. At present, we observe - partly because of the need to address new and very complicated policy challenges such as public health issues and global warming - that it is now time for a new policy paradigm that focuses on policy integration. In recent years in the Netherlands, we have observed, for instance, a clear focus on integrated policymaking with respect to spatial, environmental, and transport policies. In this study, policy integration is understood as the connection between problems, politics, policy instruments and technology for emission level reduction in metropolitan areas.

We have chosen to make a policy instrument selection (beside technology) consisting of LEZs, restrictions in parking license issuance, subsidy incentives, market based incentives, road fuel excise duties, parking rate, car sharing, electric vehicle rate and the adoption of clean technology. Policy measurements such as road pricing (Schmutzler, 2011), the adoption of public charging infrastructure and public procurement (Egnér and Trosvik, 2018) are not part of the local policy instrument selection in this study, because these have not been widely adopted in the Randstad and the RhineRuhr metropolitan area yet. In conclusion, LEZs, restrictions in parking license issuance, subsidy incentives, market based incentives, road fuel excise duties, parking rate discounts, car sharing, electric vehicle rate and the adoption of clean technology will be examined as local policy instruments in the Randstad and the Rhine-Ruhr metropolitan areas in the following section.

\subsection{Local policy instruments for road vehicle emissions reduction}

\subsubsection{Low emission zones (LEZs)}

Most cities in the Randstad and the Rhine-Ruhr metropolitan area introduced LEZs in 2008. The Randstad started with LEZs for diesel trucks below the Euro 4 norm, whereas the Rhine-Ruhr metropolitan area introduced LEZs for all diesel and petrol vehicles. In the Randstad, Amsterdam expanded its LEZ in 2018 to include older diesel-powered light duty vehicles and scooters/ mopeds made before 2011. A study of Amsterdam's LEZ for heavy vehicles from 2007 to 2010 shows a substantial decline of $4.9 \%$ for $\mathrm{NO}_{2}$ levels, 5.9\% for NOx levels and 5.8\% for $\mathrm{PM}_{10}$ (Panteliadis et al., 2014). This trend has also been confirmed for other Randstad cities from 2007 to 2010 (Boogaard et al., 2012). Utrecht and Rotterdam have expanded their LEZs to include all Euro 4 diesel vehicles. Since 2015, petrol cars without a Euro norm have not been allowed in Utrecht. In Utrecht, the effect of the LEZ on NOx air pollution was to some degree positive. After the LEZ was introduced in Utrecht, NOx declined by less than $1 \%$, and $\mathrm{NO}_{2}$ decreased by around $2 \%$. In addition, there was a significantly stronger positive effect on $\mathrm{PM}_{10}$ emission levels, which decreased by approximately $5 \%$. The LEZ in Utrecht thus seems to have a slightly positive effect on urban air quality (Eijk and Voogt, 2016). Since 2017, licence plate scanners and driver information with (electronic) signs have regulated vehicles entering the LEZ in Rotterdam. Fig. 2 shows that LEZs and parking licence refusals have caused a substantial decrease in old light diesel vehicles in the Randstad (CBS, 2017).

The air quality in Cologne, Dusseldorf, and Duisburg is also regulated by LEZs. Cars entering the LEZs in these three cities require a green sticker, and cars with yellow or red stickers are no longer allowed. Residents owning a diesel car can apply for a green
Old light diesel vehicles in 4 large cities

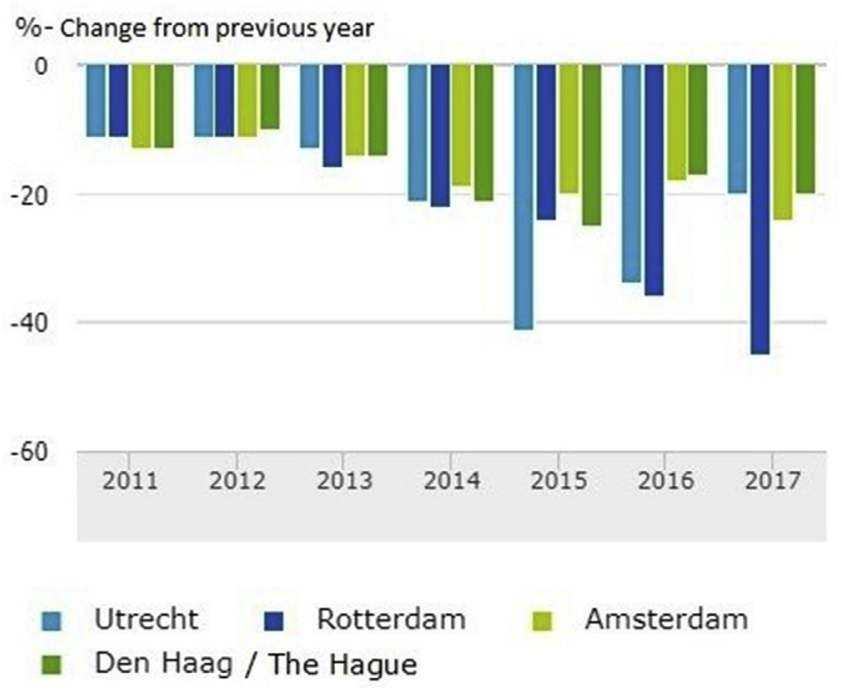

Fig. 2. Old light diesel vehicles in four Randstad cities. Source: CBS (2017).

sticker if their vehicle conforms to the Euro 3 standard or higher, with a particle filter, and when purchased after January 1, 2001. A diesel car that is subject to the Euro 4 standard or higher and purchased after January 1, 2006, is also allowed to enter these LEZs. For petrol cars, Euro standard 1 to 6 applies, and the production date of the car should be after January 1, 1993. Gas fuelled, hydrogen, electric, and hybrid cars are granted the green sticker without any further requirements. If no green sticker can be presented in a LEZ, the offender is fined $€ 80$ (Umweltplakette.de, 2018). German cities that have introduced LEZs show a positive effect on air quality ( $-17 \%$ for $\mathrm{PM}_{10},-0.3 \%$ for $\mathrm{NO}_{2},-6.9 \%$ for $\mathrm{NOx}$ ) although the potential of further reduction through additional LEZs seems to be small (Jiang et al., 2017). In the Rhine-Ruhr metropolitan area however, including Cologne and Düsseldorf, as presented by the German Federal Ministry of Environment, the number of aging but still compliant diesel cars was stable between 2007 and 2013 with the introduction of LEZs (Umweltbundesamt, 2015b).

\subsubsection{Parking licence restriction}

Parking licence restrictions for diesel and old petrol cars also impact urban emissions levels. A study showed the limited effect of raising parking rates for more polluting car categories, especially for cars with a simple or no soot filter or NOx converter $(-0.2$ to $-5.1 \%$ for NOx, -6.5 to $-11 \%$ for PM; Blom et al., 2006). The major Randstad cities, among them Amsterdam, Rotterdam, and Utrecht, stopped issuing new parking licences in 2015, and in 2016 for diesel cars below the Euro 5 standard. In Amsterdam, the parking licence restriction was adopted in 2009, because parking rate increases had a limited effect on improving the urban air quality $(-1.3 \%)$. In Amsterdam, diesel cars purchased before 2005 are not granted a parking licence. Furthermore in Amsterdam, carbon fuel vehicles (LPG, CNG, E15 and E85) purchased before July 1, 1992, are subject to parking licence restrictions. Cars older than 40 years are not granted a parking licence (Municipality of Amsterdam, 2018a). In Rotterdam, parking licence restriction also applies to petrol or LPG cars manufactured before 1992. Diesel cars bought before 2001 are not granted a parking licence either. Various emergency and community services have exemptions from the parking licence restriction (Overheid.nl, 2018). 
In Cologne, Dusseldorf, and Duisburg, residents are granted a parking licence regardless of the technical specifications of the car. Other requirements apply, such as having a residence in the relevant city and, as in the case of Cologne, not having a private parking place. Parking licence restriction, as in different cities in the Randstad, does not exist in the Rhine-Ruhr metropolitan areas (Municipality of Cologne, 2018; Municipality of Dusseldorf, 2018; Municipality of Duisburg, 2018). Therefore, in the Rhine-Ruhr metropolitan area, LEZs remain the principal policy instrument for the municipalities rather than parking license restrictions.

\subsubsection{Subsidy incentives: car wreckage premium}

In the Randstad, a number of local governments have taken the initiative to adopt subsidy incentives. The Municipality of Amsterdam has introduced a subsidy for companies to purchase electric vehicles, which is $€ 5000$ for cars and a $20 \%$ compensation (max $€ 40,000$ ) for vans, buses, and trucks (Municipality of Amsterdam, 2018b). In Amsterdam, no subsidy for car scrappage exists anymore. Rotterdam has implemented temporary subsidies in recent years, with a subsidy of $€ 500$ for owners who scrap their light duty vehicles (diesel < Euro 5, also petrol $<1992$ in Rotterdam) (Municipality of Rotterdam, 2018). Today in Germany, subsidy incentives comprise around $6 \%$ of all policy instruments that aim at a better air quality, varying from mobile to stationary sources. In recent years, urban policy makers have mostly adopted subsidy incentives as a market-based instrument in the German cities (Umweltbundesamt, 2015a).

\subsubsection{Market based incentives: road pricing and congestion charge}

Excluding a number of experimentations, the authorities have not adopted road pricing on a major scale in the Randstad and in the Rhine-Ruhr metropolitan areas. In the Randstad, road pricing experienced limited support in Dutch society by the end of the 1990's. Opposition rose against the redistributive effects of road pricing and the supposed inefficient allocation effects. Only respondents that experienced severe congestion in their daily lives supported road pricing to a certain extent. At the same time, it was found that road pricing could only be successful if the underlying social goal would be sufficiently communicated towards the public (Verhoef et al., 1997). In 2001, after societal opposition, the Dutch government put road pricing aside. Today, the Dutch government still has not adopted road pricing in the Randstad.

In the Rhine-Ruhr metropolitan area, the authorities did not adopt road pricing, by way of a congestion charge, on a major scale as well. According to the Umweltbundesamt, 2010, a congestion charge is only possible if the authorities develop a smart package of local transport and environmental policies. Good communication, investments in public transport and additional transport planning would be necessary in addition to a congestion charge. Moreover, the adoption of parking charges and parking management would be effective. At the same time, it was believed that the most effective measurement would be a higher fuel taxation in combination with a congestion charge. As in the case of the Randstad, the German authorities did not initiate road pricing in the Rhine-Ruhr metropolitan area yet.

\subsubsection{Road fuel excise duties}

In 2018, Germany had a lower road fuel duty compared to the Netherlands, both for petrol and for diesel (Fig. 3). In 2018, the fuel duty on petrol was 0.65 euro in Germany and 0.78 euro in the Netherlands. In that same year, the diesel duty on $1 \mathrm{~L}$ diesel was 0.47 euro in Germany, while the Dutch diesel duty was 0.49 euro. Road fuel excise duties may affect emissions levels significantly, because private car owners pay for fuel consumption (and with that for emissions). Therefore, road fuel excise duties may have a
Road fuel excise duties per litre (in euro), 2018

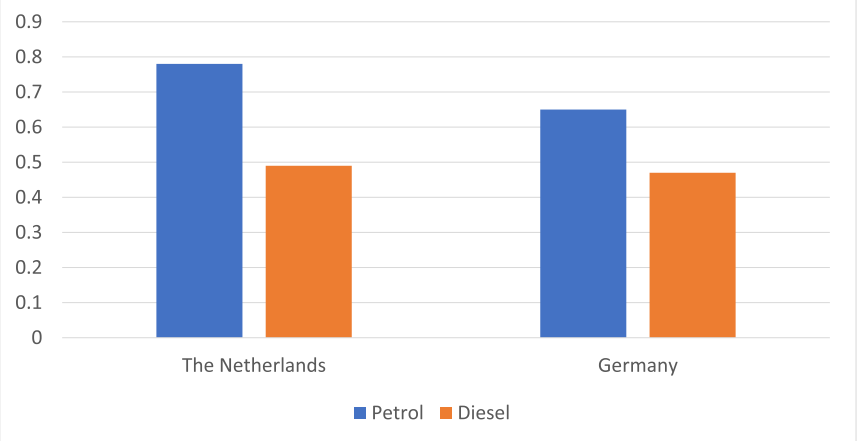

Fig. 3. Road fuel excise duties in the Netherlands and Germany, 2018. Source: European Environment Agency (2019).

Table 1

Anticipated light EV growth in a city with lower EV parking rates.

\begin{tabular}{lllll}
\hline Parking discount & $25 \%$ & $50 \%$ & $75 \%$ & $100 \%$ \\
\hline EV growth 2025 & $0.3-1.8 \%$ & $0.6-3.6 \%$ & $0.9-5.3 \%$ & $1.2-7.1 \%$ \\
EV growth 2030 & $0.3-1.8 \%$ & $0.6-3.7 \%$ & $0.9-5.5 \%$ & $1.2-7.5 \%$ \\
\hline
\end{tabular}

significant impact on emission levels in metropolitan areas.

\subsubsection{Parking rate discounts for electric vehicles}

According to Schroten et al. (2019), a parking rate discount for light battery or fuel cell electric vehicles contributes to lower emission levels. A parking discount of $25 \%$ increases electric vehicle usage between 0.3 and $1.8 \%$ in metropolitan areas by 2030 . If the parking discount rises to $100 \%$, the share of electric vehicles extends to $7.5 \%$ by 2030 . In summary, the adoption of a parking rate discount has a significant positive effect on electric vehicle usage in metropolitan areas (see Table 1).

When this policy instrument would be applied to all Dutch municipalities, it would lead to a $\mathrm{CO}_{2}$ reduction ranging from 1,200 tons (25\% discount) to 3,600 tons (100\% discount) by 2025 (Schroten et al., 2019). For the major Randstad cities ( $\pm 1.5 \mathrm{M}$ cars; CBS, 2016), this would result in an emission reduction between 240 and 750 tons by 2025 . These reductions however, are only exhaustbased.

\subsubsection{Car sharing}

As depicted in Fig. 4, the availability of shared car services is

Total shared cars/1000 inhabitants (2017)



Fig. 4. Car sharing in terms of total shared cars per 1000 inhabitant, 2017. Source: CROW-KpVV (2017) and Bundesverband CarSharing (2019). 


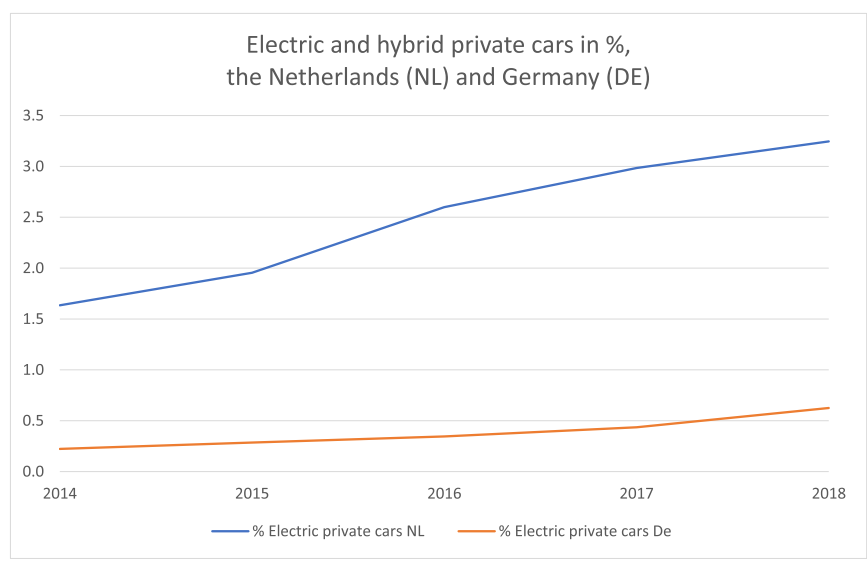

Fig. 5. The market share of electric and hybrid cars in the Netherlands and Germany, 2014-2018. Source: CBS Statline (2019b) and Kraftfahrt Bundesamt (2019)a,b.

limited in both the Randstad and the Rhine-Ruhr metropolitan area. In 2017, Utrecht had the highest car sharing rate with 7.39 shared cars per 1000 inhabitants. Amsterdam had the second position in car sharing with 6.49 cars per 1000 inhabitants, while Rotterdam scored significantly lower with 2.7 shared cars per 1000 inhabitants (CROW-KpVV, 2017). However, car sharing scored even lower in the Rhine-Ruhr metropolitan area in 2017. In Cologne, each 1000 inhabitants shared 1.27 cars on average, while car sharing in Dusseldorf and Duisburg was insignificant (Bundesverband CarSharing, 2019). Car sharing is a more widely known phenomenon in the Randstad compared to the Rhine-Ruhr metropolitan area. Nonetheless, car sharing will not significantly affect urban emission levels due to its relative limited market share in both metropolitan areas (see Fig. 5).

Both countries experience a rise in the share of the electric car fleet, though the level of market share remains relatively low. According to the CBS (2019b), in the Netherlands the share of electric private vehicles had increased from 1.6\% in 2014 to 3.2\% in 2018. Circa 270 thousand electric cars were registered in the Netherlands in 2018. In Germany, the share of electric and hybrid cars had risen from $0.2 \%$ in 2014 to $0.6 \%$ in 2018 . In total, almost 290 thousand electric and hybrid cars were registered in Germany in 2018. Although Germany has more electric and hybrid cars compared to the Netherlands in absolute numbers, its relative share is lower due to a large total car fleet (more than 46 million German private vehicles were registered in 2018) (Kraftfahrt Bundesambt, 2019a,b). In summary, due to the limited electric car fleet in relative terms in both the Randstad and the Rhine-Ruhr metropolitan area, we expect that electric cars will not significantly reduce emission levels yet.

\subsection{Technology}

Besides local policy instruments, technology is an important stream to identify urban emission levels in the Randstad and the Rhine-Ruhr metropolitan areas (Parissien, 2013; Moran and Shapiro, 2006).

\subsubsection{Weight reduction}

Weight reduction in road vehicles leads to a substantial reduction of $\mathrm{CO}_{2}$ emissions, by requiring fewer engine revolutions to attain the same velocity. A weight reduction of $100 \mathrm{~kg}$ leads to a $\mathrm{CO}_{2}$ reduction of $6 \mathrm{~g} / \mathrm{km}$ and $\pm 0.05 \mathrm{~g} / \mathrm{km}$ of NOx and PM (ICCT, 2017). To realize substantial weight reductions in road vehicles, the transition from steel to aluminium, fibreglass, carbon fibre, and HD polyethylene as building materials will be essential. When weight reduction is strongly incentivized by tax breaks for car manufacturers, or car owners that install aftermarket parts, it could lead to an annual $\mathrm{CO}_{2}$ reduction of $\pm 200,000$ tons in the larger Randstad cities and 1,2 million tons in the Rhine-Ruhr cities per year, with proportionate NOx and PM reductions of less than 1\% (CBS, 2016-2019; Regionaldatenbank Deutschland , 2019).

\subsubsection{Fuel injection}

Fuel injection has transitioned from inefficient carburettors to various electronic fuel injections with optional mist spraying intakes. Fuel injection has continued to evolve towards the even more efficient homogeneous charge (HC) injection. Retrofitting an older petrol or diesel vehicle with a mist intake that sprays water/alcohol or water/ether blends can reduce NOx and PM emissions close to zero (Chapman and Boehman, 2008). Hydrogen or HHO gas spraying intakes increase torque and can reduce up to $30 \%$ fuel consumption and $\mathrm{CO}_{2}$ emissions, but require condensed water and hydrogen producing parts (Green Car Congress, 2005, 2006). The next generation of engines with the ultra-lean $\mathrm{HC}$ injection reduces $\mathrm{CO}_{2}$ emissions by $15 \%$ compared to regular EF injection. NOx or PM emissions reduce even more with alcohol blends and variable compression. However, only a small number of light vehicle manufacturers may introduce these engines in Western Europe.

\subsubsection{New fuels}

Over the last decade, many new fuels have been in developed. Some of these fuels have a promising potential (ethanol, butanol, DME), but these have not enough compatibility for use in current vehicles. Other fuels, such as octanol and limonene from microorganisms and hydrogen from fuel cells could provide a breakthrough in lower vehicle emissions, especially for long range use. Hydrogen however, is still mostly produced by reforming LPG $(38 \mathrm{~g} /$ $\mathrm{km} \mathrm{CO}_{2}$ ). Hydrogen production by wind power and photo catalysis could lower vehicle emissions to zero, but fuel cells still require new materials to lower the total chain emissions by $240 \mathrm{~g} / \mathrm{km}$ (AIP, 2014). A cheaper alternative to the hydrogen fuel cell is the ammonia fuel cell that doesn't use noble metals and emits only water and nitrogen (Service, 2018). In contrast to electric vehicles, fuel cell vehicles help to purify the air by filtering out particulate matter for a pure chemical reaction of oxygen with fuel.

\subsubsection{Energy storage}

In battery technologies, the most used lithium-ion batteries with cobalt-nickel or iron-phosphate cathodes are evolving towards metal-pyrophosphate cathodes, with greater energy densities, voltage, and power. These batteries may still not lower the prices of electric vehicles, because of the growing scarcity of lithium, cobalt and nickel worldwide (Bannon, 2017). In the 2020's, several electric vehicle (EV) producers will incorporate sodium to nanopolymer, magnesium to xerogel, calcium to iron cyanides or various halogen-ion batteries into light vehicles, with integrated cellulosic materials (AIP, 2014; Lipson et al., 2015). This will result in a large variety of cost-efficient electric vehicles affordable to the masses, because of the use of widely available raw materials. These batteries reduce $\mathrm{CO}_{2}$ emissions below $10 \mathrm{~g} / \mathrm{km}$. Instead of batteries, buses and trucks with ultra-capacitators from earth alkalinetitanium oxides (also known as 'capavehicles') are useful for municipal services that want to transition to electric vehicles in a cost-efficient way. These buses and trucks use city infrastructure such as overhead power lines to recharge quickly (AIP, 2014). This technology has already been used on hybrid buses, trams, and short-range capabuses (see Table 2). 


\subsubsection{Estimated effects}

Using vehicle ownership statistics, Table 3 gives an overview of the annual environmental effects estimates when different technologies would be widely adopted in the Randstad and the RhineRuhr metropolitan areas. The $\mathrm{CO}_{2}$ reduction of some technologies can only be accomplished using an abundant resource, a low $\mathrm{CO}_{2}$ footprint or a circular economic approach to reach the desired effects along the whole well-to-wheel chain.*

\subsection{Impact evaluation of policy and technology efforts}

In this section, the recent effects of the discussed local policies are evaluated by conducting a trend analysis on $\mathrm{NO}_{2}, \mathrm{NOx}, \mathrm{PM}_{10}$, and $\mathrm{PM}_{2.5}$ in the Randstad and the Rhine-Ruhr metropolitan area.

\subsection{1. $\mathrm{NO}_{2}$ concentrations}

For nitrogen dioxide concentrations $\left(\mathrm{NO}_{2}\right)$, the effects of the implemented local policies on $\mathrm{NO}_{2}$ reduction are significant in both the Randstad and the Rhine-Ruhr metropolitan areas, with the exception of Cologne. Utrecht and Duisburg have complied with the EU norm in recent years. A relative significant $\mathrm{NO}_{2}$ reduction has mostly been visible in Amsterdam, Rotterdam, Utrecht and to a lesser extent Dusseldorf. On the contrary, in Cologne $\mathrm{NO}_{2}$ concentrations had increased from $31 \mu \mathrm{g} / \mathrm{m} 3$ in 2007 to $42 \mu \mathrm{g} / \mathrm{m} 3$ in 2017 , just above the EU norm. In 2017, Amsterdam and Rotterdam just complied with the EU norm (Fig. 6). In most city centres however, the trend of decreasing concentrations has ended in recent years, creating a necessity for new policy measures to prevent $\mathrm{NO}_{2}$ increases.

\subsubsection{NOx concentrations}

Fig. 7 shows that NOx concentrations (in $\mu \mathrm{g} / \mathrm{m}^{3}$ ) (a combination of $\mathrm{NO}$ and $\mathrm{NO}_{2}$ ) had declined in the Randstad and the Rhine-Ruhr metropolitan areas between 2007 and 2017. Dusseldorf and Duisburg however, had been confronted with a stable level of NOx concentrations since 2014, while the decline in NOx concentrations had continued in the other Dutch and German cities. More data is required to investigate whether the decline in NOx concentrations has continued in the Rhine-Ruhr metropolitan area after 2016.

\subsection{3. $P M_{10}$ concentrations}

Concerning $\mathrm{PM}_{10}$ emissions (Fig. 8), it becomes clear that both the Randstad and the Rhine-Ruhr metropolitan areas meet the EU $\mathrm{PM}_{10}$ norm of $40 \mu \mathrm{g} / \mathrm{m}^{3}$. In Amsterdam, between 2007 and 2017, $\mathrm{PM}_{10}$ concentrations had reduced from 24 to $22 \mu \mathrm{g} / \mathrm{m}^{3}$. In the same period, PM concentrations in Rotterdam had decreased from 33 to $21 \mu \mathrm{g} / \mathrm{m}^{3}$, and in Utrecht from 29 to $19 \mu \mathrm{g} / \mathrm{m}^{3}$. The Rhine-Ruhr metropolitan area had also shown a constant decrease in $\mathrm{PM}_{10}$ levels between 2007 and 2017. Thus, both the Randstad and the Rhine-Ruhr metropolitan area had met the EU norm for $\mathrm{PM}_{10}$ of 40ug/ $\mathrm{m}^{3}$ between 2007 and 2017.

\subsection{4. $P M_{2.5}$ concentrations}

Fig. 9 shows a declining trend in $\mathrm{PM}_{2.5}$ concentration levels in the Randstad and in the Rhine-Ruhr metropolitan areas between 2008 and 2017. In addition, both the Randstad and the Rhine-Ruhr

Table 2

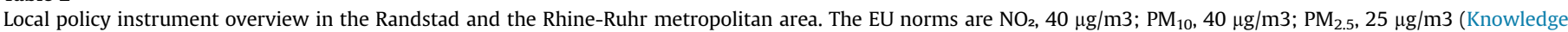
Centre InfoMil, 2019). Source: Authors' figure based on ANWB (2017), Audit Room Amsterdam (2011), Umweltbundesamt, 2015a.

\begin{tabular}{|c|c|c|c|c|c|c|c|c|c|c|}
\hline Case & Problem & $\begin{array}{l}\text { Stake- } \\
\text { holders' } \\
\text { interests }\end{array}$ & LEZ & $\begin{array}{l}\text { Parking } \\
\text { licence } \\
\text { restriction }\end{array}$ & $\begin{array}{l}\text { Adapted or } \\
\text { alternative infra- } \\
\text { structure }\end{array}$ & $\begin{array}{l}\text { Electric vehicle } \\
\text { support }\end{array}$ & $\begin{array}{l}\text { Motor- way } \\
\text { toll }\end{array}$ & $\begin{array}{l}\text { LEZ } \\
\text { info } \\
\text { system }\end{array}$ & $\begin{array}{l}\text { Average } \mathrm{NO}_{2} \\
\text { level in centre } \\
\mu \mathrm{g} / \mathrm{m} 3\end{array}$ & $\begin{array}{l}\text { Avrg PM10 } \\
\text { level in centre } \\
\mathrm{ug} / \mathrm{m} 3\end{array}$ \\
\hline Amsterdam & $\begin{array}{l}\text { Polluted } \\
\text { crossroads, more } \\
\text { asthma, strokes }\end{array}$ & $\begin{array}{l}\text { No LEZ for } \\
\text { scooters }\end{array}$ & $\begin{array}{l}\text { Diesel: < Euro } \\
4\end{array}$ & $\begin{array}{l}\text { Diesel: < Euro } \\
\text { 4, Petrol: } \\
<1992\end{array}$ & $\begin{array}{l}\text { New north-south } \\
\text { metro line }\end{array}$ & $\begin{array}{l}\text { 2016, only } \\
\text { companies }\end{array}$ & $\begin{array}{l}\text { In } 2020 \text { s for } \\
\text { trucks } \\
\text { nationally }\end{array}$ & Yes & 38 & 21 \\
\hline Rotterdam & $\begin{array}{l}\text { Polluted } \\
\text { crossroads, more } \\
\text { asthma, strokes }\end{array}$ & $\begin{array}{l}\text { Allow }<92 \\
\text { petrol cars }\end{array}$ & $\begin{array}{l}\text { Diesel: < Euro } \\
\text { 5, Petrol: < } \\
\text { Euro } 1\end{array}$ & $\begin{array}{l}\text { Diesel: < Euro } \\
5\end{array}$ & $\begin{array}{l}\text { Extended metro line, } \\
\text { fewer car lanes in } \\
\text { centre }\end{array}$ & $\begin{array}{l}€ 500 \text { for light } \\
\text { diesel } \\
\text { scrappage }\end{array}$ & $\begin{array}{l}\text { In } 2020 \text { s for } \\
\text { trucks } \\
\text { nationally }\end{array}$ & Yes & 39 & 20 \\
\hline Utrecht & $\begin{array}{l}\text { Polluted } \\
\text { crossroads, more } \\
\text { asthma, strokes }\end{array}$ & $\begin{array}{l}\text { Ban }<92 \\
\text { petrol cars }\end{array}$ & $\begin{array}{l}\text { Diesel: < Euro } \\
5\end{array}$ & $\begin{array}{l}\text { Diesel: < Euro } \\
5\end{array}$ & $\begin{array}{l}\text { Extended fast tram/ } \\
\text { light rail }\end{array}$ & $\begin{array}{l}\text { Subsidy for } \\
\text { light diesel } \\
\text { scrappage }\end{array}$ & $\begin{array}{l}\text { In } 2020 \text { s for } \\
\text { trucks } \\
\text { nationally }\end{array}$ & Yes & 25 & 19 \\
\hline Cologne & $\begin{array}{l}\text { Polluted } \\
\text { crossroads, more } \\
\text { asthma, strokes }\end{array}$ & $\begin{array}{l}\text { No } \\
\text { motorway } \\
\text { toll }\end{array}$ & $\begin{array}{l}\text { Diesel: < Euro } \\
5\end{array}$ & $\begin{array}{l}\text { Diesel: < Euro } \\
\text { 5, Petrol: }< \\
\text { Euro } 1\end{array}$ & Cycling lanes & No & $\begin{array}{l}\text { From } 2019 \\
\text { nationally }\end{array}$ & Yes & 43 & 20 \\
\hline Dusseldorf & $\begin{array}{l}\text { Polluted } \\
\text { crossroads, more } \\
\text { asthma, strokes }\end{array}$ & $\begin{array}{l}\text { No } \\
\text { motorway } \\
\text { toll }\end{array}$ & $\begin{array}{l}\text { Diesel: < Euro } \\
5, \mathrm{P}<\text { Euro } 1\end{array}$ & $\begin{array}{l}\text { Diesel: }<\text { Euro } \\
\text { 5, petrol: }< \\
\text { Euro } 1\end{array}$ & Cycling lanes & E-bus line & $\begin{array}{l}\text { From } 2019 \\
\text { nationally }\end{array}$ & Yes & 56 & 26 \\
\hline Duisburg & $\begin{array}{l}\text { Polluted } \\
\text { crossroads, more } \\
\text { asthma, strokes }\end{array}$ & $\begin{array}{l}\text { No } \\
\text { motorway } \\
\text { toll }\end{array}$ & $\begin{array}{l}\text { Diesel: }<\text { Euro } \\
\text { 5, petrol: }< \\
\text { Euro } 1\end{array}$ & $\begin{array}{l}\text { Diesel: }<\text { Euro } \\
\text { 5, petrol: }< \\
\text { Euro } 1\end{array}$ & Cycling lanes & No & $\begin{array}{l}\text { From } 2019 \\
\text { nationally }\end{array}$ & Yes & 37 & 21 \\
\hline
\end{tabular}

Table 3

Overview of emission effects per technology. Source: CBS (2019c); Regionaldatenbank Deutschland (2019).

\begin{tabular}{|c|c|c|c|c|c|c|}
\hline Technology & $\begin{array}{l}-100 \mathrm{~kg} \text { weight in } \\
\text { cars }\end{array}$ & $\begin{array}{l}\text { Mist intake in } \\
\text { cars }\end{array}$ & $\begin{array}{l}\text { HHO intake in } \\
\text { cars }\end{array}$ & $\begin{array}{l}\text { Electric cars with } \\
\text { renewables }\end{array}$ & $\begin{array}{l}\text { With }<10 \mathrm{~g} / \mathrm{km} \mathrm{CO}_{2} \text { footprint } \\
\text { batteries }\end{array}$ & $\begin{array}{l}\text { Electric heavy vehicles with new } \\
\text { media }\end{array}$ \\
\hline $\begin{array}{l}\text { Vehicles in } \\
\text { Randstad }\end{array}$ & $1,5 \mathrm{mln}$ & $1,5 \mathrm{mln}$ & $1,5 \mathrm{mln}$ & $1,5 \mathrm{mln}$ & $1,5 \mathrm{mln}$ & 30,000 \\
\hline Tons of $\mathrm{CO}_{2}$ & $-0,165 \mathrm{mln}$ & $-0,3 \mathrm{mln}$ & $-1,25 \mathrm{mln}$ & $-2,4$ to $2,5 \mathrm{mln}$ & $-2,7$ to $-2,8 \mathrm{mln}$ & -300 \\
\hline $\mathrm{NOx} / \mathrm{PM}$ & -1000 to -2000 & $\begin{array}{l}-1300 \\
\text { to }-1600\end{array}$ & $\begin{array}{l}-5000 \text { to } \\
10,000\end{array}$ & -12 , to $-13,000$ & -18 , to 20,000 & -5 to -10 \\
\hline $\begin{array}{l}\text { Vehicles in Rhine- } \\
\text { Ruhr }\end{array}$ & $7,5 \mathrm{mln}$ & $7,5 \mathrm{mln}$ & $7,5 \mathrm{mln}$ & $7,5 \mathrm{mln}$ & $7,5 \mathrm{mln}$ & 540,000 \\
\hline Direct tons of $\mathrm{CO}_{2}$ & $-1,2 \mathrm{mln}^{*}$ & $-1,77 \mathrm{mln}$ & $-6,65 \mathrm{mln}$ & -15 to $-16 \mathrm{mln}^{*}$ & -17 to $-18 \mathrm{mln}^{*}$ & $-14,500^{*}$ \\
\hline $\mathrm{NOx} / \mathrm{PM}$ & $-10,000$ & -10 to 12,000 & -30 to 45,000 & -70 , to 80,000 & -80 , to $-90,000$ & \pm-300 \\
\hline
\end{tabular}







Amsterdam (2014-2016), RIVM (2008-2014), LANUV (2018a,b), Knowledge Centre InfoMil (2019), Umwelt Bundesamt (2019).

\section{NOx yearly average $(\mu \mathrm{g} / \mathrm{m} 3)$ in city centres}

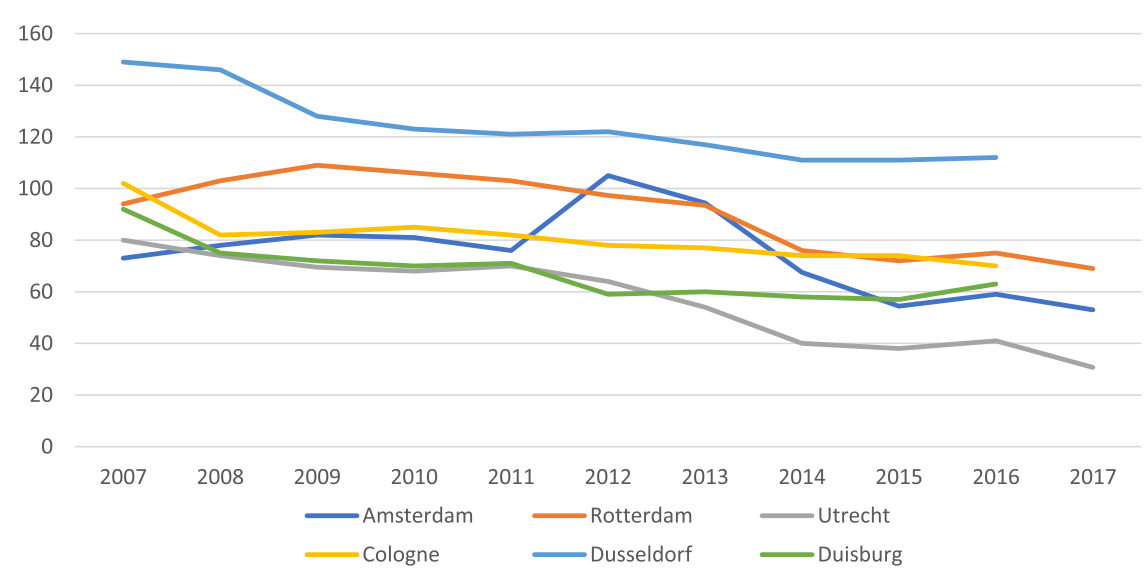


(2008-2014).

metropolitan area had met the EU norm of $\mathrm{PM}_{2.5}$ in this period. In 2017, Duisburg had the lowest $\mathrm{PM}_{2.5}$ concentration of $10 \mu \mathrm{g} / \mathrm{m}^{3}$ from all the examined Randstad and Rhine-Ruhr cities. Since 2012, Utrecht has had the lowest $\mathrm{PM}_{2.5}$ concentrations compared to the other Randstad cities. Thus, $\mathrm{PM}_{2.5}$ concentration levels had steadily declined and had met the EU norm in both the Randstad and the Rhine-Ruhr metropolitan area between 2008 and 2017.

In summary, concerning $\mathrm{NO}_{2}, \mathrm{NOx}, \mathrm{PM}_{10}$, and $\mathrm{PM}_{2.5}$ levels in the Randstad and the Rhine-Ruhr metropolitan areas, an overall downward trend is visible. Concerning $\mathrm{NO}_{2}$ in the Randstad and the Rhine-Ruhr metropolitan areas, Duisburg and Utrecht had been able to meet the $\mathrm{EU} \mathrm{NO}_{2}$ air quality requirements since 2011. Amsterdam and Rotterdam were just able to meet the $\mathrm{NO}_{2}$ emission norms in 2017. The EU air quality norms had not yet been met in Cologne and Dusseldorf by 2017 (the EU standard for $\mathrm{NO}_{2}$ is $40 \mu \mathrm{g} /$ $\mathrm{m}^{3}$ ). Dusseldorf and Cologne need to effectuate additional policy to comply with the EU emissions standards. NOx concentrations in the Randstad and in Cologne had declined recently, but Dusseldorf and Duisburg have shown a stabilizing trend in NOx concentrations in recent years. Concerning $\mathrm{PM}_{10}$ and $\mathrm{PM}_{2.5}$ levels, the authorities in both the Randstad and the Rhine-Ruhr metropolitan areas had been able to meet the EU air quality standards.

\subsubsection{The underestimated relevance of modal split performance}

Beside the impact of local policy instruments on the emission levels in metropolitan areas, local policy instruments also have influence on the modal split. In the Randstad, in particular in Amsterdam and in Utrecht, bike usage and walking are dominant. The share of biking and walking had been quiet stable over time (around 58\% from 2011 to 2017). Additionally, in Amsterdam the share in car use is around 20\% (CBS, 2015, 2019; Ministry of Infrastructure and the Environment/KiM, 2017). In the RhineRuhr metropolitan area however, the car is the most dominant mode of transport. In this German metropolitan area, the share of 
PM10 yearly average $(\mu \mathrm{g} / \mathrm{m} 3)$ in city centres

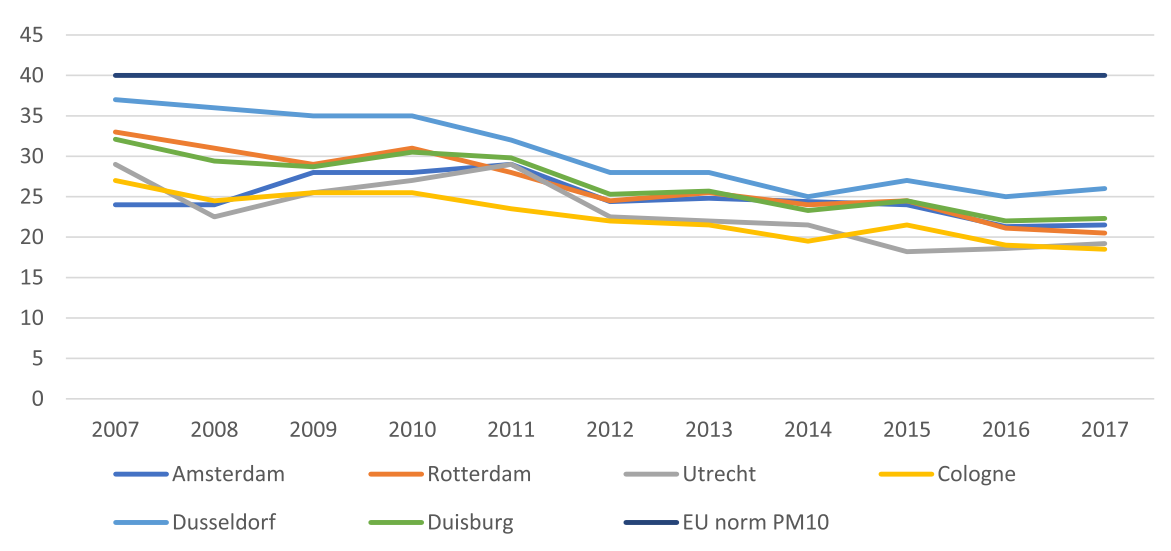



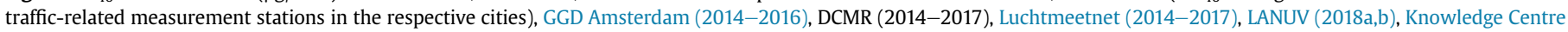
InfoMil (2019).

PM2.5 yearly average $(\mu \mathrm{g} / \mathrm{m} 3)$ in city centres

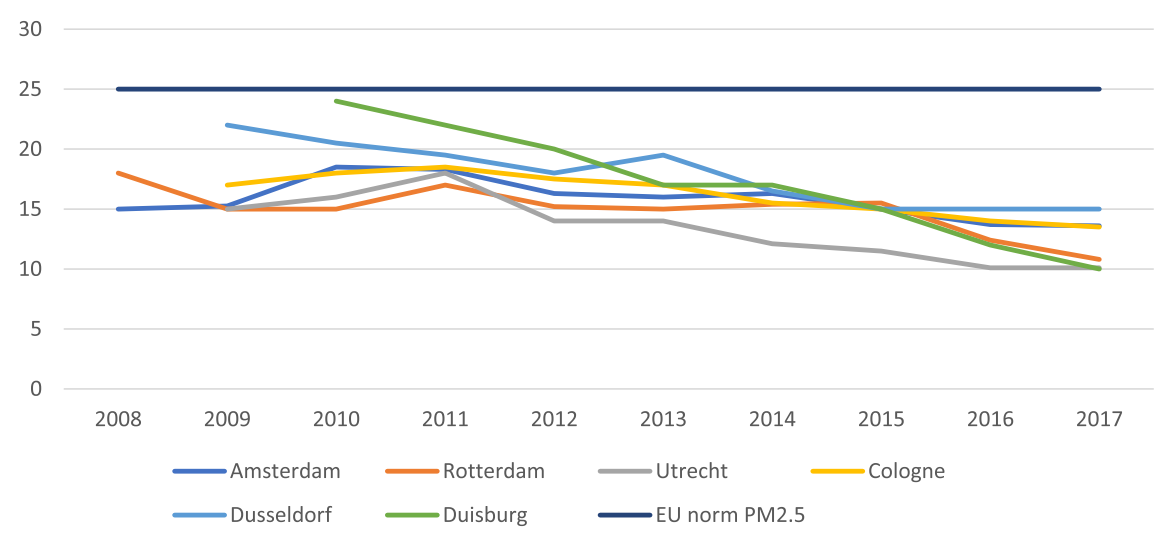

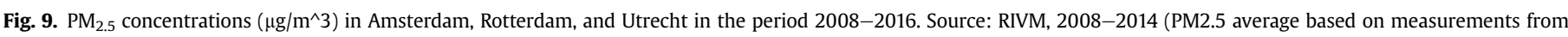

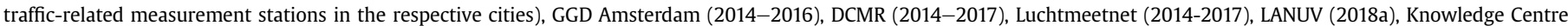
InfoMil (2019), Umweltbundesamt (2019).

the car varies between $40 \%$ (Cologne) and 57\% (Duisburg) in the modal split (Deutscher Bundestag, 2017). This is a remarkable observation, because we expect that alternative modes of transport would become more popular. However, there are indications that car usage is a culturally determined factor in Germany due to the car manufacturing tradition. For freight transport, a modal split policy has been on the agenda of the Randstad and the Rhine-Ruhr cities only recently. Amsterdam and Rotterdam are stimulating logistics companies to prepare zero emission zones for the future (ZEZs) with the launch of Green Deal Zero Emission plans. The Rhine-Ruhr cities are still leaving the initiative to the private sector (Green-Zones GmbH, 2019).

\section{Conclusion}

In this study, the application of interpretative policy analysis (Yanow, 2014) and a cross-case comparison (Yin, 2003) on local policy instruments, technology, and vehicle-related emissions identified a slightly positive effect on reducing air pollutant concentrations in the Randstad and the Rhine-Ruhr metropolitan areas. The research incorporated an inductive approach as well and found novel insights into the relationship between local policy instruments, technology, and vehicle-related emissions.

Before discussing the main findings and implications for mobility policy and future research that can be drawn from the findings, some research limitations with regard to the results are applicable. First, the limitation of interpretive policy analysis is that no direct causality between local policy instruments, technology and vehicle-related emissions can be proved. However, we can identify a relation, because the adopted policy instruments, technological solutions and vehicle-related emissions have objectively been mapped. By doing so, the adopted interpretive policy analysis and cross-case comparison are up to the current state-of-the-art. Second, it is complex to quantify the uncertainty levels of certain policies such as parking rates policy, public transport services and traffic volume, because the 'open systems' nature of local policy 
makes it difficult to find quantifiable weights on these parameters. Open systems imply that local policy instruments interact with their surroundings and entail large uncertainty levels (Rotmans, 2005). Furthermore, emission sources other than road traffic, such as inland navigation, aviation, and industry can affect the air quality of city centres in some circumstances. Hence, the application of interpretative policy analysis and a cross-case comparison enable a thick qualitative description (Evers, 2016) of the relation between local policy instruments, technology, and vehicle-related emissions. This brings us to the main research question and the extent to which local mobility policies and technologies have been adopted among different actors to reduce vehicle-related NOx and PM levels in the Randstad and the Rhine-Ruhr metropolitan areas, and the extent to which these local mobility policy and technologies have been successful.

\subsection{Changing emission profiles in the Randstad and the Rhine-Ruhr metropolitan area}

The study shows that $\mathrm{NO}_{2}, \mathrm{NOx}, \mathrm{PM}_{10}$, and $\mathrm{PM}_{2.5}$ levels in the Randstad and the Rhine-Ruhr metropolitan areas have dropped significantly over the years. Concerning $\mathrm{PM}_{10}$ and $\mathrm{PM}_{2.5}$, the authorities in the Randstad and the Rhine-Ruhr metropolitan areas have even met the EU air quality standards. With respect to $\mathrm{NO}_{2}$, the EU air quality norms have not yet been met in the Randstad and the Rhine-Ruhr. Only Duisburg and Utrecht were able to meet the EU $\mathrm{NO}_{2}$ air quality requirements since 2010 respectively 2012. Amsterdam and Rotterdam have met the $\mathrm{NO}_{2}$ EU emission norm just recently (2017), but Cologne and Dusseldorf still need to effectuate policy to comply with the $\mathrm{EU} \mathrm{NO}_{2}$ emission standards. In particular Dusseldorf lacks behind and needs to take further measures to improve its NOx levels.

There is not always a direct causality between a specific measure and the measurable effect: the effect of each individual instrument independently is sometimes hard to identify. However, all instruments together enable a lowering of emission levels in both the Randstad and the Rhine-Ruhr metropolitan area. Furthermore, we found that local policies are effective, but there is also a relation with national policies such as a road fuel duty. Possibly as the result of this combination, in the Randstad bike usage and walking have become dominant and have remained stable in the modal split over time, while in the Rhine-Ruhr metropolitan area, the car is the dominant mode of transport. Still in both metropolitan areas we studied, the collaborative use of policy and market instruments, including the adoption of clean mobility technology, had a positive impact on the reduction of emission levels. This relates in particular to the adoption of LEZs, restrictions in parking license issuance, subsidy incentives, market based incentives, road fuel excise duties, parking rate, car sharing, electric vehicle rate and the adoption of clean technology. All these measurer together contribute to lower emission levels in the Randstad and the Rhine-Ruhr metropolitan area.

In more detail, we can make the following observations. First, in the case of Dutch cities, sanction-based instruments initially caused a substantial decrease in air pollutant concentrations. In more recent years however, instruments such as parking licences and expanded LEZs have created a flight to cheaper but more polluting two-wheeled vehicles. From recent reports, there are indications that further expansions of LEZs to other vehicles or segments in Dutch cities are still politically controversial. LEZs in general have already been characterized by some political parties in the Dutch parliament as ineffective instruments, because of the minor results of the 2014 expansion for diesel cars in Utrecht. Such findings confirm the uncertainty of success in implementing policy measures with some controversy. In Amsterdam with large numbers of scooters and mopeds, a proposed LEZ for these vehicles has been met with resistance from vehicle associations that have been lobbying for several years for a scrappage subsidy. In Rotterdam, the controversial expansion of a LEZ for petrol vehicles older than 1992 could be implemented in other cities soon, with the desire of the Rutte III administration to harmonize LEZs in major cities. This might lead to large protests, a continuation of the transition to more polluting two-wheeled vehicles that started in late 2017, and an increase in air pollutants just outside of the zones. In the RhineRuhr metropolitan area with a history of bad air quality, the introduction of LEZs has had a minor effect on vehicle replacements in most cities. Despite the lack of tax-burdening measures and the high popularity of two-wheeled vehicles, there was still a substantial decrease in air pollutants. However, LEZs in Germany have lost their relative efficacy with the recent economic growth and more road traffic.

Market-based policy instruments in the Netherlands have so far not produced the desired outcome for vehicle replacements and emission reductions, especially for petrol vehicles, but also for diesel vehicles because of their greater fuel efficiency. Road fuel duties on fuel and a vehicle registration tax (VRT) that increases prices for new petrol cars and lowers them for older cars have caused an increase in Euro 3/4 cars, mostly with lease drivers. The Netherlands had a segmented VRT system with exemptions for EVs and ultra-low emission vehicles from 2010 to 2015 that has been continued only for EVs and hybrids since 2016. A comparison of tax-burdening market-based policy instruments between countries reveals that Germany has had a more constant replacement of vehicles with only fuel duties as a tax-burdening regulation. This could change, however, with the introduction of a motorway toll in 2019. With stimulating market-based instruments in Germany, vehicle replacements for municipal services are now the most employed policy instrument to improve air quality. Many cities in the Rhine-Ruhr metropolitan area have now replaced their municipal fleet with electric or ultra-low emission vehicles and will soon add or tender electric buses and waste trucks. Stimulating instruments for electric or hybrid vehicles have already led to a minor increase in sales of these vehicles in the Netherlands and Germany, especially for duty vehicles in cities. However, German commuters have recently lost some interest in these stimulating instruments for EVs, resulting in fewer EV purchases. Including more options for the private sector to avail of these instruments and informing actors about the different options for financial rewards and sustainable technology application will have a positive effect on fuel efficiency, lower vehicle emissions, and improved air quality in urban areas.

New technologies are not always cost efficient enough to involve all actors and their segments in reducing vehicle emissions without substantial government incentives. The extreme example of this situation can be seen with the crash in the EV market in Denmark, but also with the stagnating EV market in Germany and with all light vehicles sales in the Netherlands in 2016. In particular, lower budget companies and commuters still have difficulties transitioning to hybrid or electric vehicles with few cost-efficient options available and fears over long recharging times, battery damaging quick-charges and battery replacement costs in the future. New technologies without financial incentives are not attractive enough to involve all actors and their economic segments in vehicle emissions reductions. For now, these segments that barely comply with LEZs and shift emissions to just outside LEZ borders can only to a minor extent be stimulated with tax discounts, incentives, and information campaigns. This situation could be changed, however, by introducing cheaper modifications to the vehicle market that improve engine combustion, and later by the development of electric vehicle technologies, producing more cost- 
efficient alternatives with improved driving range and recharging.

\subsection{Policy recommendations}

Policymaking is mainly focusing on policy options, instruments or assessment methods, rather than on decision-making processes and/or implementation issues; little attention has been given to organizational and/or institutional aspects of policy integration. It is also observed that the adoption of local policy instruments does not incorporate a linear adoption of policy goals, alternatives, alternative evaluation and choosing a particular local policy instruments as they are embedded in large uncertainties. Given the results of the evaluation of the effectiveness of different policy instruments and technologies, the following policy recommendations can be made for urban municipalities in the Netherlands and Germany, their national governments, and vehicle associations:

- Continuing the change in city infrastructure that promotes clean mobility and discourages or complicates combustion engine traffic. Increasing the number of pedestrian zones, cycle lanes, and electric charging stations by municipalities facilitates the ease and comfort of using non-polluting vehicles. Reducing car lanes in busy city streets and raising parking tariffs and parking licence fees in busy streets for combustion engine vehicles discourages combustion vehicle traffic and stimulates clean mobility.

- Enforcing LEZs with licence plate scanners, barcode stickers, and portable emission meters by municipal inspectors and police to enforce LEZs on newer as well as on modified vehicles. This measure ensures compliance with LEZs in urban areas and results in a faster transition to lower vehicle emissions.

- Phasing out older diesel engine buses and waste trucks in cities can make small to substantial emissions reductions possible, depending on the average age of public service vehicles in a city. The choice of transitioning to electric, diesel-hybrid, or LPG/ DME-fuelled vehicles should depend on the routes and costs of these vehicles.

- Subsidies and tax discounts for the purchase of cleaner vehicles or modifications. These economic policy instruments are a good addition to implement a clean air policy in cities because of their stimulating effect on sales of cleaner vehicles or modifications and the phasing out of older polluting vehicles. These measures are effective in phasing out older petrol or newer diesel vehicles with better fuel consumption that otherwise would keep circulating in cities for many more years. In Germany, an expansion of sanction-based measures could be implemented more easily with an extension of the national E-Auto subsidy and lower toll rates for electric vehicles from 2019 onwards. In the Netherlands, local governments could use subsidies to accelerate a cost-efficient transition from old polluting twowheeled vehicles to electric scooters and to help reduce ultrafine dust emissions in cities with many scooters. Registration with a green energy provider could also be used as a strict condition for tax discounts and lower toll rates to guarantee more $\mathrm{CO}_{2}$ reductions from electric vehicles and more investments in renewable energy.

- Developing a green label for electric and hybrid vehicles. This instrument could stimulate manufacturers to build vehicles with eco-friendly, abundant, and local resources, reducing the carbon footprint of these vehicles and prices for consumers.

- Enhancing the concept of integrated policy making with an emphasis on decision-making processes and implementation issues in real practice that comprises organizational and/or institutional aspects of policy integration.

\subsection{Scientific recommendations}

First, the theoretical implications following from the research in this study indicate a greater difficulty of aligning perceived problems with solutions when there is little flexibility in actors' interests, policy instruments, and technologies. This development can be observed with the fixation on fully electric vehicle purchases in cities and national sales bans on combustion engine vehicles in the future. However, there is not yet enough infrastructure, renewable power generation, or power storage technology suitable to everyone to realize these policy plans. A further study on the network development and market instruments that are necessary to familiarize and standardize the production and use of bio- or synthetic fuels and cheaper electric vehicles will give a better understanding of the dynamics between consumer, producer, and government interests in the pursuit of cleaner vehicles and better air quality.

Second, the original STREAMS model lacks systematic analysis of the interaction between policy development and environmentally friendly technologies. The dominant theoretical focus on policymaking lacks insights into how policymakers, producers, and consumers develop, design, and use environmentally friendly vehicle technologies. In this article, we have bridged this gap by adopting the concept of the infrasystem (Loorbach et al., 2010). Infrasystems are a valuable conceptual framework to explain the positive and negative environmental effects of policy instruments and technology, because infrasystem theory enables us to analyse hardware technology and social (policy) systems in an integral manner. Consequently, we have added a new technology stream to Kingdon (1984) STREAMS model. However, much more research is needed on the interaction between social (policy) systems and technology.

Third, given the 'open systems' nature of this research (Rotmans, 2005), it is hard to find a causality between perceived policy, technology, and measured $\mathrm{NO}_{2}$, NOx, and PM levels in the Randstad and the Rhine-Ruhr metropolitan areas. In this research, we have not controlled the relation between policy, technology, and $\mathrm{NO}_{2}$, NOx, and PM levels for the economic situation. Consequently, although we can uphold an association between policy, technology, and the $\mathrm{NO}_{2}$, NOx, and PM levels in the Randstad and the RhineRuhr metropolitan areas, in a new research, we intend to control for the economic situation to find a stronger association between policy, technology, and harmful vehicle emissions.

\section{Declaration of competing interest}

The authors declare that they have no known competing financial interests or personal relationships that could have appeared to influence the work reported in this paper.

\section{Appendix A. Supplementary data}

Supplementary data to this article can be found online at https://doi.org/10.1016/j.jclepro.2019.119175.

\section{References}

Adams, M., 2017. Air Quality in Europe. Status and Opportunities. European Environment Agency. http://mfvm.dk/fileadmin/user_upload/MFVM/Miljoe/ Luftvision/EEA_Air_pollution_Ren_luft-vision_1June2017.pdf. accessed 18 May 2018.

American Institute of Physics (AIP), 2014. Energy storage in miniaturized capacitors may boost green energy technology. https://www.sciencedaily.com/releases/ 2014/01/140117153639.htm accessed 20 September 2019.

ANWB, 2017. Vervuilende brommers vanaf 2018 uit verkoop. https://www.anwb.nl/ verkeer/nieuws/nederland/2017/mei/vervuilende-brommers-vanaf-2018-uitverkoop accessed 19 May 2018. 
Audit Room Amsterdam (Rekenkamer Amsterdam), 2011. Luchtkwaliteit in Amsterdam, June 2011.

Balser, M., Bauchmüller, M., 2018. EU-kommissar Will Länder Wegen Schlechter Luftqualität Verklagen. Süddeutsche Zeitung. http://www.sueddeutsche.de/ politik/luftverschmutzung-eu-kommissar-will-laender-wegen-schlechterluftqualitaet-verklagen-1.3927922. accessed 17 May 2018.

Bannon, E., 2017. Electric vehicle life cycle analysis and raw material availability. https://www.transportenvironment.org/publications/electric-vehicle-lifecycle-analysis-and-raw-material-availability accessed 20 September 2019

Blom, M.J., Schroten, A., Van Essen, H.P., 2006. Milieueffecten Van Differentiëren Van Parkeertarieven. CE Delft. August 2006

Boogaard, H., Janssen, N.A.H., Fischer, P.H., 2012. Impact of low emission zones and traffic policies on ambient air pollution concentrations. Sci. Total Environ. 132-140. https://doi.org/10.1016/j.scitotenv.2012.06.089.

Brünekreef, B., Holgate, S.T., 2002. Air pollution and health. The Lancet 360 (9341) 1233-1242. https://doi.org/10.1016/S0140-6736(02)11274-8.

Bundesverband-Carsharing, 2019. CarSharing-städteranking in 2017. https:/ carsharing.de/sites/default/files/uploads/rangliste_carsharing-staedteranking 2017.pdf accessed May 2019.

CBS, 2017. Helft oude diesels in Rotterdam in 2016 van de straat. https:/www.cbs. nl/nl-nl/nieuws/2017/27/helft-oude-diesels-in-rotterdam-in-2016-van-destraat accesssed 21 September 2019.

CBS, 2019a. Regional Statistics of The Netherlands. CBS Data. https://opendata.cbs. nl/statline/\#/CBS/nl/dataset/70072ned/table?ts=1565115140178.

CBS, 2019b. Market Share of Electric Cars. CBS Data. https://opendata.cbs.nl/ statline/\#/CBS/nl/dataset/71405ned/table?dl=1E944.

CBS, 2019c. Motorvoertuigenpark; Motorvoertuigen Van Particulieren. CBS Data. https://statline.cbs.nl/Statweb/search/?Q=motorvoertuigen\&LA=NL.

Chapman, E.M., Boehman, A.L., 2008. Pilot ignited premixed combustion of dimethyl ether in a turbodiesel engine. Fuel Process. Technol. 89 (12), 1262-1271. https://doi.org/10.1016/j.fuproc.2008.08.010.

CROW-KpVV, 2017. Autodelen. https://kpvvdashboard-4.blogspot.com/ accessed 11 May 112019.

Deutscher Bundestag, 2017. Modal split in ausgewählten deutschen Großstädten. https://www.bundestag.de/resource/blob/535044 f9877fd834da2c1bf7c7bb02299da09e/wd-5-084-17-pdf-data.pdf accessed 11 May 2019.

Dias, D., Tchepel, O., Pais, A.A., 2016. Integrated modelling approach for the evaluation of low emission zones. J. Environ. Manag. 177, 253-263. https://doi.org/ 10.1016/j.jenvman.2016.04.031.

Egnér, F., Trosvik, L., 2018. Electric vehicle adoption in Sweden and the impact of local policy instruments. Energy Policy 121, 584-596. https://doi.org/10.1016/ j.enpol.2018.06.040.

Eijk, A., Voogt, M., 2016. Effectmeting milieuzone personen- en bestelverkeer in Utrecht, p. 4. TNO 2016 R10230, March 25 ${ }^{\text {th }}, 2016$.

Ellison, R.B., Greaves, S.P., Hensher, D.A., 2013. Five years of London's low emission zone: effects on vehicle fleet composition and air quality. Transp. Res. D Transp. Environ. 23, 25-33. https://doi.org/10.1016/j.trd.2013.03.010.

Enserink, B., Koppenjan, J.F.M., Mayer, I.S., 2012. A policy sciences view on policy analysis. In: Thissen, W.A.H., Walker, W.W. (Eds.), Public Policy Analysis. New Developments. Springer Verlag, Heidelberg/London/New York/Dordrecht, pp. $11-40$.

European Environment Agency, 2019. Road fuel excise duties. https://www.eea. europa.eu/data-and-maps/daviz/road-fuel-excise-duties accessed 11 May 2019.

Evers, J.C., 2016. Elaborating on thick analysis: about thoroughness and creativity in qualitative analysis. Forum Qual. Soc. Res. 17 (1),1-21. https://doi.org/10.17169/ fqs-17.1.2369.

Geerlings, H., Stead, D., 2003. The integration of land use planning, transport and environment in European policy and research. Transp. Policy 10 (3), 179-196. https://doi.org/10.1016/S0967-070X(03)00020-9.

Gehrsitz, M., 2017. The effect of low emission zones on air pollution and infant health. J. Environ. Econ. Manag. 83, 121-144. https://doi.org/10.1016 j.jeem.2017.02.003.

GGD Amsterdam, 2014-2016. Luchtverontreiniging Amsterdam. https://www luchtmeetnet.nl/download accessed 18 May 2018.

Green Car Congress, 2005. Hydrogen-enhanced combustion engine could improve gasoline fuel economy by $20 \%$ to $30 \%$. http://www.greencarcongress.com/2005/ 11/hydrogenenhance.html/ accessed 20 September 2019.

Green Car Congress, 2006. Thermoelectric-powered hydrogen injection system. http://www.greencarcongress.com/2006/08/thermoelectricp.html/ accessed 20 September 2019

Green-Zones GmbH, 2019. Das Urteil: gesundheit geht vor Mobilität!. http://www. dieselfahrverbote.de/ accessed 4 October 2019.

Hackney, J.D., Linn, W.S., Buckley, R.D., 1975. Experimental studies on human health effects of air pollutants. Arch. Environ. Health 30, 8. https://doi.org/10.1080 00039896.1975 .10666730$.

Holman, C., Harrison, R., Querol, X., 2015. Review of the efficacy of Low Emission Zones to improve urban air quality in European cities. Atmos. Environ. 111 161-169. https://doi.org/10.1016/j.atmosenv.2015.04.009.

Jiang, W., Boltze, M., Groer, S., Scheuvens, D., 2017. Impacts of low emission zones in Germany on air pollution levels. Transportation Research Procedia 25, 3370-3382. https://doi.org/10.1016/j.trpro.2017.05.217.

Katsouyanni, K., Touloumi, G., Spic, C., Schwartz, 1997. Short term effects of ambient sulphur dioxide and particulate matter on mortality in 12 European cities: results from time series data from the APHEA project. Britisch.Med. J. 314
1658-1663.

Kingdon, J.W., 1984. Agendas, Alternatives and Public Policies, second ed. Longman, Boston.

Knowledge Centre InfoMil, 2019. Grenswaarden en andere luchtkwaliteitsnormen. https://www.infomil.nl/onderwerpen/lucht-water/luchtkwaliteit/regelgeving/ wet-milieubeheer/beoordelen/grenswaarden/accessed 11 May 112019.

Kraftfahrt Bundesambt, 2019a. Diagramm fahrzeugbestand in Überblick, 20142018. https://www.kba.de/DE/Statistik/Fahrzeuge/Bestand/j\%C3\%A4hrlich/ 2018/2018 b bestand_node.html accessed 11 May 2019.

Kraftfahrt Bundesamt, 2019b. Jahresbilanz der Neuzulassungen 2018. https://www. kba.de/DE/Statistik/Fahrzeuge/Neuzulassungen/n_jahresbilanz.html? $\mathrm{nn}=644522$ accessed 10 May 2019.

LANUV, 2018a. Kurzfassungen Jahreskenngrößen Kontinuierlich Gemessener Immissionskonzentrationen in NRW accessed 18 May 2018.

LANUV, 2018b. Umweltindikatoren nordrhein-westfalen. https://www.lanuv.nrw. de/umweltindikatoren-nrw/ accessed 18 May 2018

Lipson, A., Pan, B., Lapidus, S.H., Liao, C., 2015. Rechargeable Ca-ion batteries. A new energy storage system. Chem. Mater. 27 (24), 8442-8447. https://doi-org.ru. idm.oclc.org/10.1021/acs.chemmater.5b04027.

Loorbach, D., Frantzeskaki, N., Thissen, W., 2010. Introduction to the special section: infrastructures and transitions. Technol. Forecast. Soc. Chang. 77 (8), 1195-1202. https://doi.org/10.1016/j.techfore.2010.06.001.

Luchtmeetnet, 2014 - 2017. Rapportage. https://www.luchtmeetnet.nl/rapportage.

Malina, C., Scheffler, F., 2015. The impact of Low Emission Zones on particulate matter concentration and public health. Transp. Res. A Policy Pract. 77, 372-385. https://doi.org/10.1016/j.tra.2015.04.029.

Ministry of Infrastructure and the Environment/KiM, 2017. Mobiliteitsbeeld 2017 accessed 11 May 2019.

Moran, M.J., Shapiro, H.N., 2006. Fundamentals of Engineering Thermodynamics, fifth ed. Wiley, Chichester.

Municipality of Amsterdam, 2018a. Geen parkeervergunning voor vervuilende voertuigen. https://www.amsterdam.nl/parkeren-verkeer/parkeervergunning/ schoner-parkeren/ accessed 18 May 2018.

Municipality of Amsterdam, 2018b. Veelgevraagd, subsidies elektrische voertuigen. https://www.amsterdam.nl/veelgevraagd/ accessed 18 May 182018.

Municipality of Amsterdam, 2018c. Milieuzone. https://www.amsterdam.nl/ parkeren-verkeer/milieuzone/ accessed 20 September 2019.

Municipality of Cologne, 2018. Bewohnerparkausweis. http://www.stadt-koeln.de/ service/produkt/bewohnerparkausweis accessed 18 May 2018.

Municipality of Duisburg, 2018. Anwohnerparkausweis beantragen. https://www. duisburg.de/vv/produkte/pro_du/dez_v/61/bewohnerparkausweis-beantragen. php?cg_at_id=0 accessed 20 September 2019.

Municipality of Dusseldorf, 2018. Ausnahmegenehmigung zum Parken für Bewohner. https://www.duesseldorf.de/buergerservice/dienstleistungen/ dienstleistung/show/ausnahmegenehmigung-zum-parken-fuer-bewohner. html accessed 18 May, 2018.

Municipality of Rotterdam, 2018. Subsidie sloop personen en bestelauto's. https:// www.rotterdam.nl/loket/subsidie-sloop-autos/ accessed 18 May, 2018.

Overheidnl, 2018. Gemeenteblad: uitvoeringsbesluit parkeren Rotterdam 2016. https://zoek.officielebekendmakingen.nl/gmb-2015-129473.html accessed 18 May, 2018.

Panteliadis, P., Strak, M., Hoek, G., Weijers, E., van der, Zee S., Dijkema, M., 2014. Implementation of a low emission zone and evaluation of effects on air quality by long-term monitoring. Atmos. Environ. 86, 113-119. https://doi.org/10.1016/ j.atmosenv.2013.12.035.

Parissien, S., 2013. The Life of the Automobile. A New History of the Motor Car. Atlantic Books.

RIVM (Rijksinstituut voor Volksgezondheid en Milieu, 2008-2014. Jaaroverzicht luchtkwaliteit 2007-2013. https://www.rivm.nl/publicaties accessed 20 September 2019.

Rotmans, J., 2005. Societal Innovation: between Dream and Reality Lies Complexity. Inaugural Address. Erasmus University, Rotterdam.

Santos, F.M., Gomez-Losada, A., Pires, J.C.M., 2019. Impact of the implementation of Lisbon low emission zone on air quality. J. Hazard Mater. 365, 632-641. https:// doi.org/10.1016/j.jhazmat.2018.11.061.

Schmutzler, A., 2011. Local transportation policy and the environment. Environ. Resour. Econ. 48 (3), 511-535. https://doi.org/10.1007/s10640-010-9447-5.

Schroten, A., Scholten, P., Kok, R., Mulder, H., 2019. Stimuleren van emissieloze voertuigen via verlaagde parkeertarieven. accessed 21 September 2019. http:/ file:///C:/Users/u043137/Downloads/CE_Delft_180022_Stimuleren_ emissieloze_voertuigen_verlaagde_parkeertarieven_def.pdf.

Service, R.F., 2018. Ammonia-a renewable fuel made from sun, air, and water- could power the globe without carbon. https://www.sciencemag.org/news/ 2018/07/ammonia-renewable-fuel-made-sun-air-and-water-could-powerglobe-without-carbon accessed September 202019.

Spengler, J.D., Ferris, B.G., Dockery, D.W., Speizer, F.E., 1979. Sulfur dioxide and nitrogen dioxide levels inside and outside homes and the implications on health effects research. Environ. Sci. Technol. 13 (10), 1276-1280. https://doi-org.ru. idm.oclc.org/10.1021/es60158a013.

Statistisches Bundesamt, 2019. RegioStaR nach Fläche, Bevölkerung und Bevölkerungsdichte am 31.12.2017 accessed 6 August 2019.

Swinney, P., 2016. Building the northern powerhouse. Lessons from the rhine-ruhr and Randstad. www.centreforcities.org accessed 7 August 2019.

The International Council On Clean Transportation (ICCT), 2017. Footprint versus mass: How to best account for weight reduction in the european vehicle $\mathrm{CO}_{2}$ 
regulation. https://theicct.org/sites/default/files/CO2-reduction-technologies_ fact-sheet_10102017_vF.pdf. (Accessed 20 November 2019).

Umwelt Bundesamt, 2019. Stickstoffoxide. https://www.umweltbundesamt.de/ themen/luft/luftschadstoffe/stickstoffoxide accessed 27 September 2019.

Umweltbundesamt, 2010. Road Pricing for Cars in Germany? an Evaluation from an Environmental and Transport Policy Perspective. Dessau-Rosslau. https://www. umweltbundesamt.de/sites/default/files/medien/publikation/long/3991.pdf. accessed 11 May, 2019.

Umweltbundesamt, 2015b. Sachverständigengutachten: auswertung der Wirkungen von Umweltzonen auf die Erneuerung der Fahrzeugflotten in deutschen Städten. Endbericht. Texte 08/15, 28.

Umweltbundesamt, 2015a. Inventory and Effectiveness of Measures to Improve Air Quality. Umweltbundesamt. Texte 05/15.

Umweltplakette, de, 2018. Umweltzone köln, deutschland. https://www.umweltplakette.de/de/info-zur-deutschen-umwelt-plakette/umweltzonen-indeutschland/deutsche-umweltzonen/koeln.html accessed 18 May, 2018.

Valavanadis, A., Vlachogianni, T., Fiotakis, K., Loridas, S., 2013. Pulmonary oxidative stress, inflammation and cancer: respirable particulate matter, fibrous dusts and ozone as major causes of lung carcinogenesis through reactive oxygen species mechanisms. Int. J. Environ. Res. Public Health 10 (9), 3886-3907. https://doi.org/10.3390/ijerph10093886.

Valavanidis, A., Fiotakis, K., Vlachogianni, T., 2008. Airborne particulate matter and human health: toxicological assessment and importance of size and composition of particles for oxidative damage and carcinogenic mechanisms. J. Environ. Health.Sci., Part C 26 (4), 339-362. https://doi-org.ru.idm.oclc.org/10.1080/ 10590500802494538.

Verhoef, E.T., Nijkamp, P., Rietveld, P., 1997. The social feasibility of road pricing. A case study for the Randstad area. J. Transp. Econ. Policy 31 (3), 255-276.

World Health Organization, 2005. Effects of air pollution on children's health and development: a review of the evidence. https://apps.who.int/iris/handle/10665/ 107652 accessed 20 September 2019.

Yanow, Dvora, 2014. Interpretative analysis and comparative research. In: Engeli, I. Allison, C.R. (Eds.), Comparative Policy Studies. Conceptual and Methodological Challenges. Palgrave MacMillan, Hampshire, New York, pp. 131-159.

Yin, R.K., 2013. Case Study Research and Applications, Design and Methods, third ed. Sage Publications, Thousand Oaks. 